\title{
Ultra-aesthetics and advanced neuroplasticity or simply, a path to expanded consciousness
}

May 8, 2018

At 4:48 am, my dog Jayla scratched at the door to get out. At 4:49 am, a magnitude 4.5 earthquake on the Richter scale struck below the San Andreas Fault and everything in the bedroom started swaying. How did my dog pre-sense what we did not?

In order to understand how the senses work, I interviewed neuroscience Professor Vilayanur Ramachandran and our conversation quickly turned to synaesthesia. ${ }^{1}$ He explained how a defect in the 'pruning' gene creates a flaw in the brain circuitry that ends up creating involuntary associations that lead to synaesthesia. In this condition, numbers and colours are automatically associated in a part of the brain called the fusiform gyrus. For example, every time the synaesthete sees the number five it will appear blue.

Ramachandran and I also talked about the fine line between synaesthetes who involuntarily cross-associate different senses, and artists and poets with a propensity to use metaphors. Ramachandran's research seemed to show that the latter group has a proclivity to link seemingly unrelated concepts, because of a higher level of interconnectivity in their brains as compared to the general population. In other words, the 'flaw' in the pruning gene that synaesthetes have is the basis for artistic and poetic creativity, which is also to a great extent 'involuntary' in the poet/artist population.

\section{Greater sensing and broader brain processing}

What if we take this one step further by increasing the interconnectivity in our brains while simultaneously exploring how our senses can be enhanced, augmented, or added to? What if instead of syn-aesthetics, or the "union of the senses" as the etymology of the word implies, we consider ultra-aesthetics? Or, how we could foster sensing 'beyond' our normal capabilities, while creating ways in our consciousness to process not just the senses we have in a more interlinked and attuned way, but to encourage new processes of consciousness in the brain. This could be termed advanced neuroplasticity.

In order to wrap our heads around this idea, perhaps we need to imagine beyond the senses that are available to us, and how neuroplasticity is compensating for this lack. By this I mean the brain's ability to compensate for disease or injury by creating new neural pathways that
- Marcos Lutyens. Professor Vilayanur Ramachandran interviewed by Marcos Lutyens in https://vimeo. com/139512469. 
allow the subject to adapt to changing situations and environments. In April this year, I conducted a series of workshops with a handful of visually impaired students from the Strazdumuiža Boarding School, with the support of BlindArt and the Latvian Society of the Blind. We were talking about the association between shapes and sounds, as illustrated by psychologist Wolfgang Köhler's Bouba/Kiki experiment. ${ }^{2}$ In Köhler's experiment, a sharp, spiky form is compared to a soft, round one. The results across different cultures indicated that the spoken sound of the word "kiki" is matched with a spiky shape and the word "bouba" to a round one.

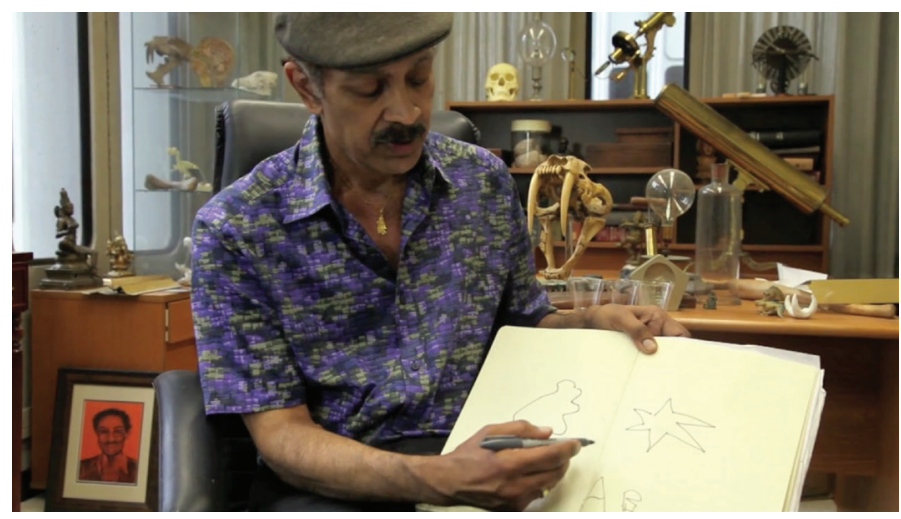

Prof. Ramachandran

In the workshop I conducted with the visually impaired, students could hear the spoken sounds, but were unable to see the shapes, as in Köhler's original experiment; instead, the students felt them as contours. The conversation then turned to colours, as our project involved a tactiledrawing process called 'geometrisation. ${ }^{3}$

Imagine that the 'colour centre' of the brain (scientifically known as V4, and includes the fusiform gyrus) is dormant in a person who has been blind since birth: brain plasticity predicts that this area of the brain will be re-appropriated by neighbouring sensory processing mechanisms. In keeping with this theory, at least one of the visually impaired students in my workshop could 'see' sounds as internally manifested colours, otherwise understood as a synaesthetically developed reconnection of neuronal channels. Other students, who also had no firsthand experiences with colour, had developed an automatic and deeply ingrained correspondence between certain colours, such as white to the physical sensations of coldness or warmth to the colour red. Textures also related to colours, such as wool to orange and a shiny surface to blue. This indicates that not just the surface texture, but also the natural heat conductance of certain materials helped them decipher what colours translate into what tactile sensations. Wool, when rubbed, creates heat and therefore can be used to describe orange, a warm colour. In the same way, glossy surfaces often feel cold which matches a cool colour such as blue. When considered from a neurological standpoint, we can appreciate a certain cobbling together of substitute neural pathways between different sensory brain processing centres to begin imagining a sense that one lacks, but that others can verify as existing.
2 Kelly McCormick, Jee Young Kim, Sara List, and Lynne C. Nygaard, "Sound to Meaning Mappings in the Bouba-Kiki Effect," Proceedings of the 37th Annual Conference of the Cognitive Science Society, Pasadena, CA, July 2015.

3 This was based on the work of visionary $20^{\text {th }}$-century Latvian artist Zanis Waldheims. 


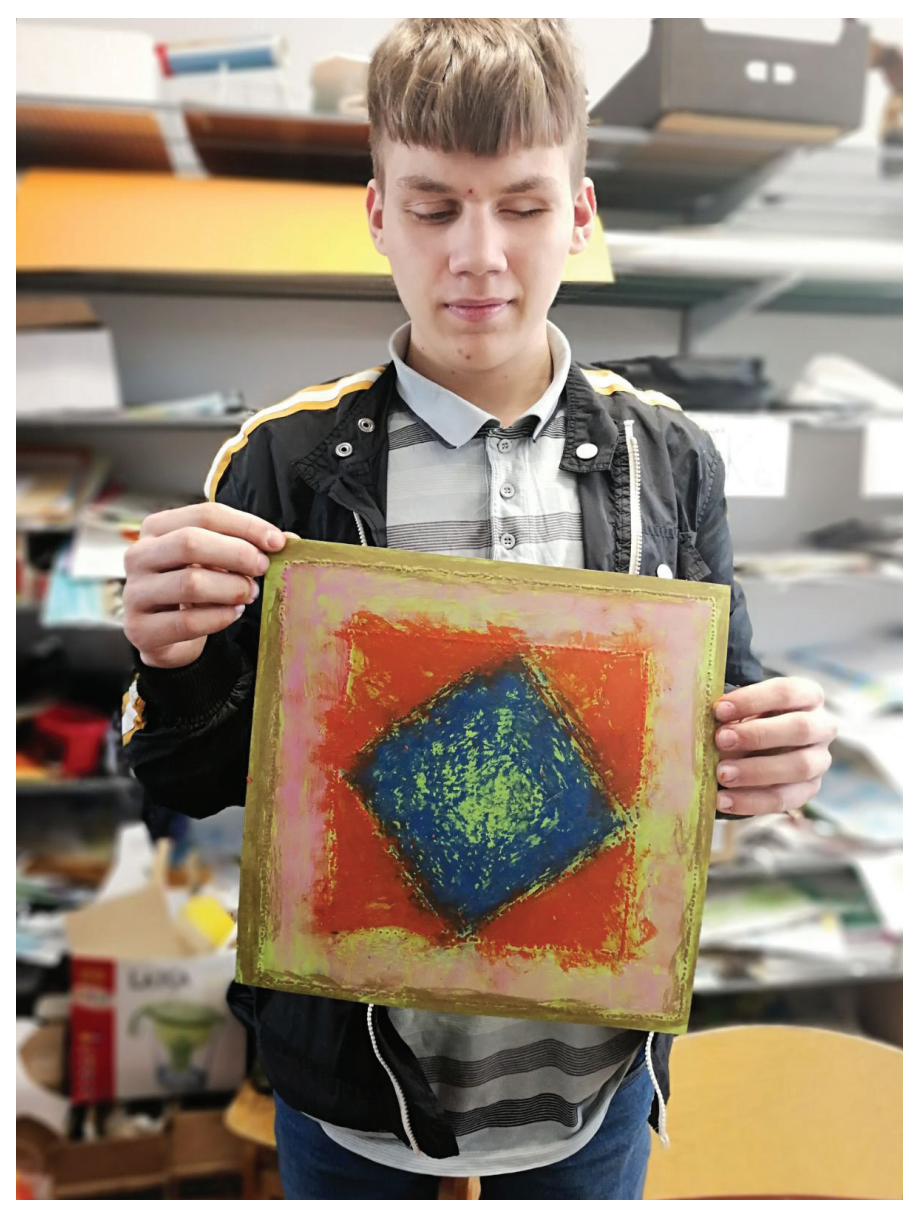

Deniss Ovsjaniikovs with drawing. Photo: Courtesy of Gerda Eglāja.

In the case of sensing imaginary warmth in relation to colour, Tibetan Buddhists are experts in the practice of Tummo, or the development of an 'inner fire'. This was brought to the West's attention by explorer and spiritualist Alexandra David Néel at the turn of the $20^{\text {th }}$ century. Rather than being a process that demonstrates how the damaged brain makes the best of existing resources, one could argue that a practice like Tummo creates a kind of brain entrainment that optimises the existing healthy brain by creating new neural pathways and networks between normally disconnected brain regions. This is what I would term advanced neuroplasticity.

\section{Neuroplastic gymnasium for new sensing}

What can we make of a sense that we think we do not have, but we are aware exists in other creatures? Is it possible to develop this ability by training certain sensitivities in latent sensory organs, while allowing our minds to translate incoming sensory signals in this new type of sense awareness?

Take for instance, the cuttlefish that 'sees' through its skin in a little understood process called crypsis. In this process, the marine animal creates the most deceptive of camouflage strategies. Even though the 

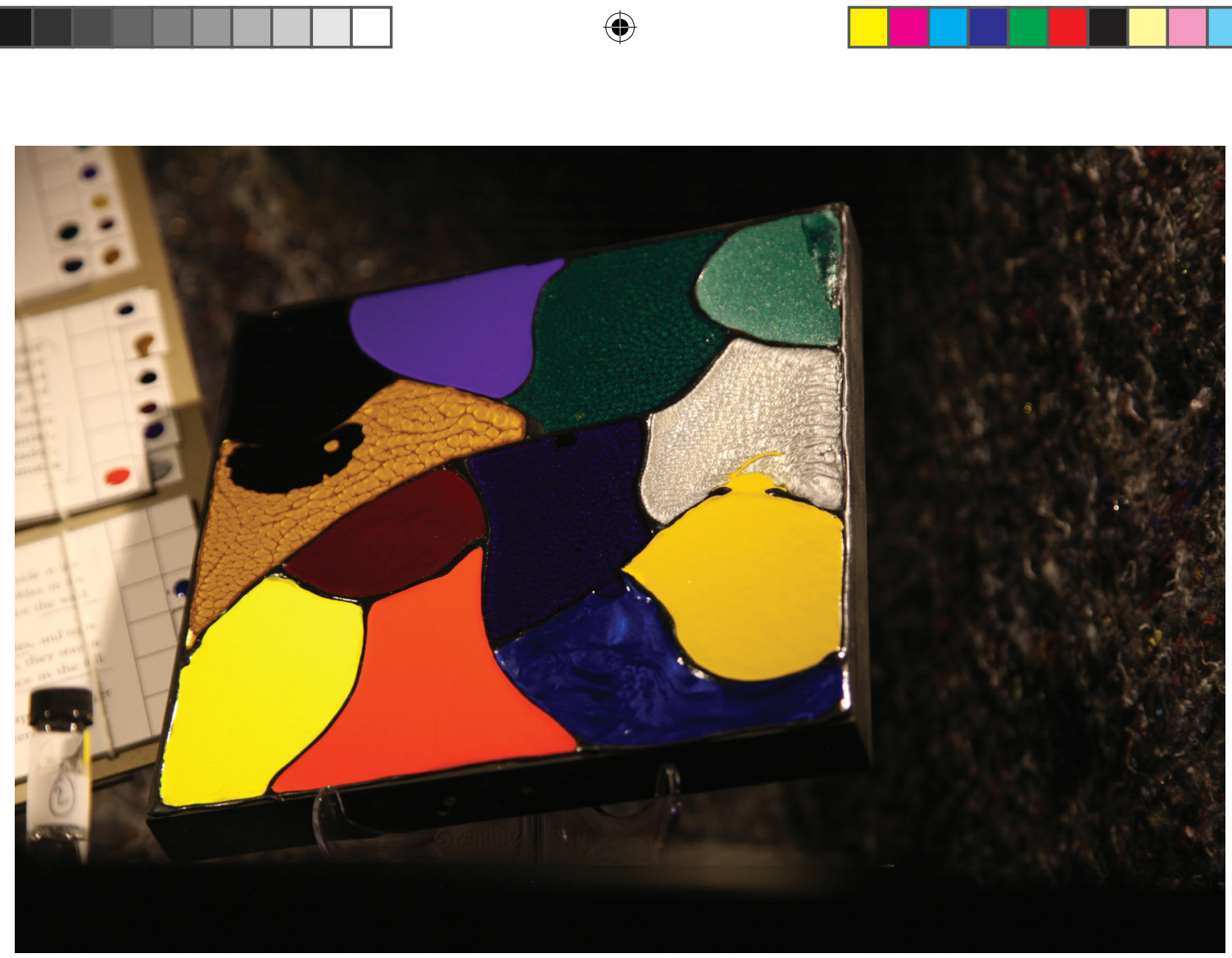

Paroptic menu, Neuarthian Boatstrap, $14^{\text {th }}$ Istanbul Biennial.

cuttlefish is colourblind, its skin can match its surroundings through chromatically complex patterns. In another example, the Surrealist author René Daumal would place colourful handkerchiefs inside a wooden box as a teenager and train himself to 'see' the colours of the cloth inside it, which he coined "paroptic vision". ${ }^{4}$ Over time, he claimed to have this ability. My own experiments involving hypnosis at Fortuny Museum in Venice and the $14^{\text {th }}$ Istanbul Biennial have been somewhat inconclusive, although I have come across certain people who seem 'gifted' with this ability, such as the artist Lea Porsager who confidently and accurately described colours that she sensed under her fingertips with her eyes closed. ${ }^{5}$

This sounds esoteric, but there is now substantial evidence that our bodies are covered in light sensitive proteins known as opsins, which detect light and dark changes around us. Opsins are best known for their work as photoreceptor cells inside the retina, which enable us to see. Furthermore, opsins in our skin are responsible for our circadian rhythms and help regulate our daily cycles as we adapt to night and day. ${ }^{6}$ These changes are sensed at an unconscious level, which is why, in trance states, this type of sensory information can be intercepted by the conscious mind. In these states, neural plasticity can take place as the brain manages to funnel unconscious processes into its higher cortical functions. It isn't much of a stretch to think that the same types of proteins that detect colours in our eyes could also differentiate a full colour spectrum through our fingertips and hence allow for paroptic vision. Why see colour through the skin other than for artistic enquiry? Perhaps there could be a selective advantage for humans, such as the ability to better adapt to seasonal light changes, a biological reason for opsins to detect colour variations in the light spectrum.

${ }_{4}$ Gary Lachman, "Climbing Mount Analogue," Quest 89.5, SeptemberOctober 2001, p. 166-171.

${ }^{5}$ The experiment at Fortuny Museum was part of the Intuition Exhibition curated by Axel Vervoordt and Daniela Ferretti. The installation at the $14^{\text {th }}$ Istanbul Biennial took place on a ship docked at the Island of Büyükada.

${ }^{6}$ Thomas Cronin, "Seeing Without Eyes," Scientific American, 13 Aug 2017. 


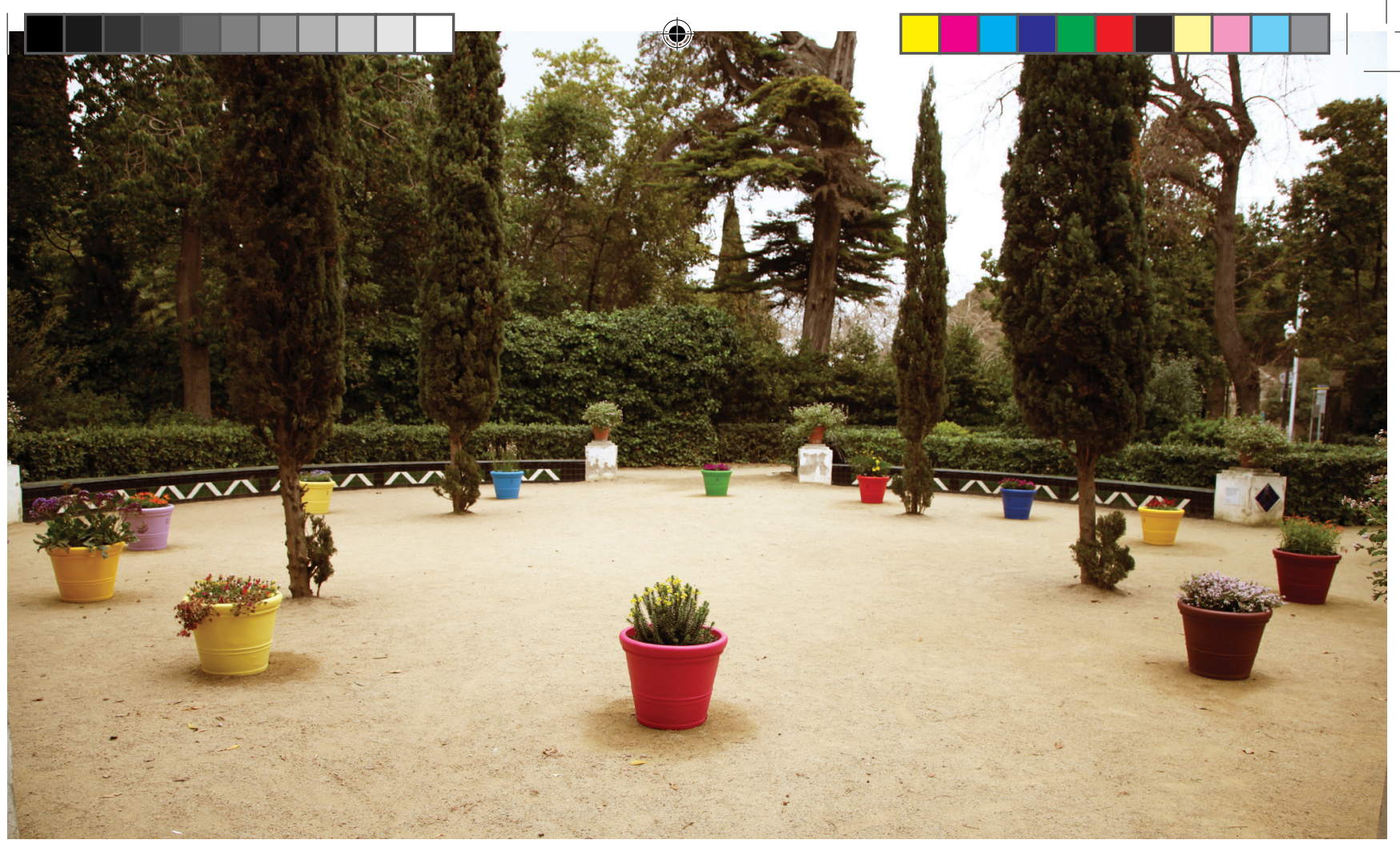

Horologium Florae, horologium Apum, Succus Aevi. Installation at Jardins de Laribal. Beehave Exhibition, Fundació Joan Miró.

Opsins are not our only skin receptors of the times of day; we also carry the 'clock' gene, variations of which exist in all animals and plants, a theory which I recently explored with Vadim de Grainville at the Fundació Joan Miró, Barcelona, in an installation titled Horologium Florae, Horologium Apum, Succus Aevi (Flower clock, Bee Clock, Time Juice). ${ }^{7}$ This piece explored circadian rhythms in plants and bees, with the aim of looping us back into our natural time cycles, which we seem to have lost as a result of exposing our eyes with non-solar light before sunrise and after sunset.

\section{Magnetoreception sensing}

Another example of a liminal sense that I investigated is magnetotactic orientation. I first became aware of it when I spoke to Patrice Garnier, a synthetic biologist in Paris. He informed me that the microbiome that we all carry in our bodies is a vast ecosystem of microorganisms that weigh approximately four kilograms and are composed of bacteria, fungi, yeasts, protozoans and viruses. ${ }^{8}$ The microbiota that live in our bellies activate the gut-brain axis that change our brain functions and, by extension, our personalities and behaviours. It's surprising to think that unicellular organisms formulate many of our desires, and that we have little or no control over them. We also discussed quorum sensing and how groups of bacteria use this method to self-regulate population density, as well as how other bacteria navigate using the earth's magnetic currents.

When I arrived back in the US, I discovered that there was a community of ferrous nano-crystal-based magnetotactic bacteria that thrive at the lowest point of North America, in the ecologically-extreme environment of Badwater Basin in Death Valley. After a long car trip past the Trona Pinnacles and the Mesquite Flat Sand Dunes, I set out to work on

7 This was curated by Martina Millà, with the expertise of Dr. Anna

Febrero Ribas, Susana Mangas and Steve Rogenstein.
${ }^{8}$ Patrice Garnier works alongside the celebrated geneticist and biological philosopher Antoine Danchin. 
verifying the sensitivity of these microorganisms to electromagnetic currents and their orientation along geomagnetic or electromagnetic fields by dint of their intracellular organelles called magnetosomes.

Relating this to our own sense of orientation, how is it that some of us seem to have a better sense of direction than others? In migratory animals that travel hundreds of miles-such as turtles, geese or salmonit's obvious that some kind of sensing related to the earth's magnetic field helps with migration routes, and allows them to locate exact geographic locations year after year. Research indicates that these magnetotactic bacteria could act symbiotically with vertebrates, especially in their lacrimal glands, to help with orientation sensing. ${ }^{9}$

Once I familiarised myself with the magnetotactic bacteria and conducted further research on magnetic sensing, I wanted to test the possibility that humans may have a dormant magnetic sensing mechanism in the ethmoid region of the head, which is between the eye socket and the back of the nose. The idea is that secretions from these ferrous bacteria stimulate an ophthalmic nerve, which subsequently sends information to the host's brain about the earth's magnetic field.

I organised a performance called In Touch with a cross section of the general public on the esplanade of Centre Georges Pompidou. ${ }^{10}$ In

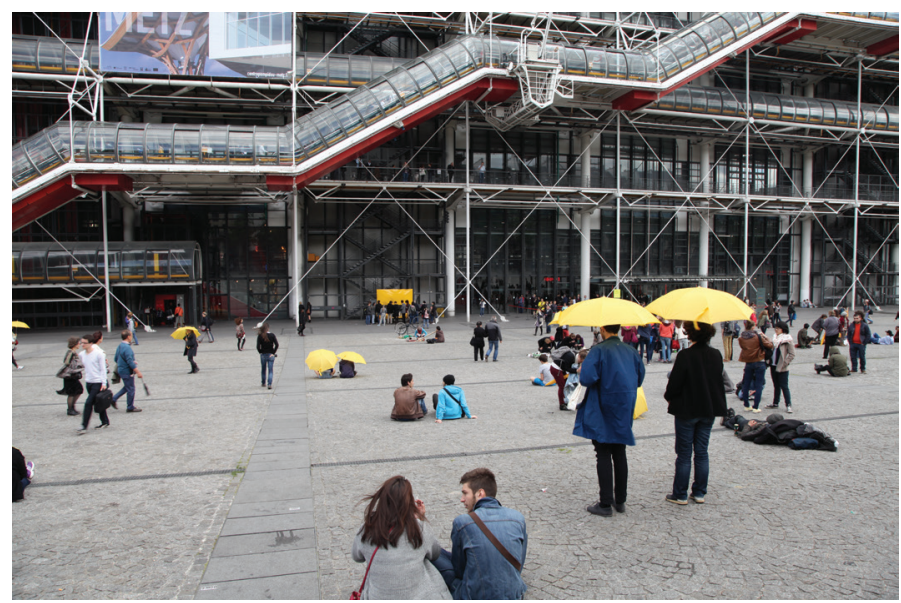

In Touch, Centre Georges Pompidou.

the performance, I invited them to listen to a hypnotic induction while wearing headphones. This allowed them to tap into their own unconscious direction-sensing signals while moving around the esplanade. The induction was designed to elicit emotive states and thus tap into the tear glands that are known to help with orientation sensing, at least in birds. ${ }^{11}$ The whole day was spent with participants wandering around the esplanade, some following rigid and determined vectors, while others meandered in a kind of Debord-like Dérive - eyes half open, led by their noses. ${ }^{12}$

At the end of the performance, some participants reported being very attuned to directionality while others, who were normally easily disoriented, found that under the inductive exercise, they could better sense the cardinal directions around them. This same exercise should be tested at different longitudes and latitudes, as well as under different
9 Natan Eviatar and Yoni Vortman, "The symbiotic magnetic-sensing hypothesis: do Magnetotactic Bacteria underlie the magnetic sensing capability of animals?" Movement Ecology, December 2017

${ }^{10}$ This was in collaboration with Centre Georges Pompidou and Galerie Alberta Pane.
"These feathered creatures actually 'see' the magnetic field fluctuations on their corneas, due to the alignment of the bacteria as they flow along the surface of their eyeballs, which enables the sunlight to polarise across them.

${ }_{12}$ Guy Debord developed a mapping strategy in 1956 in which participants would wander through the city and "let themselves be drawn by the attractions of the terrain and the encounters they find there." 


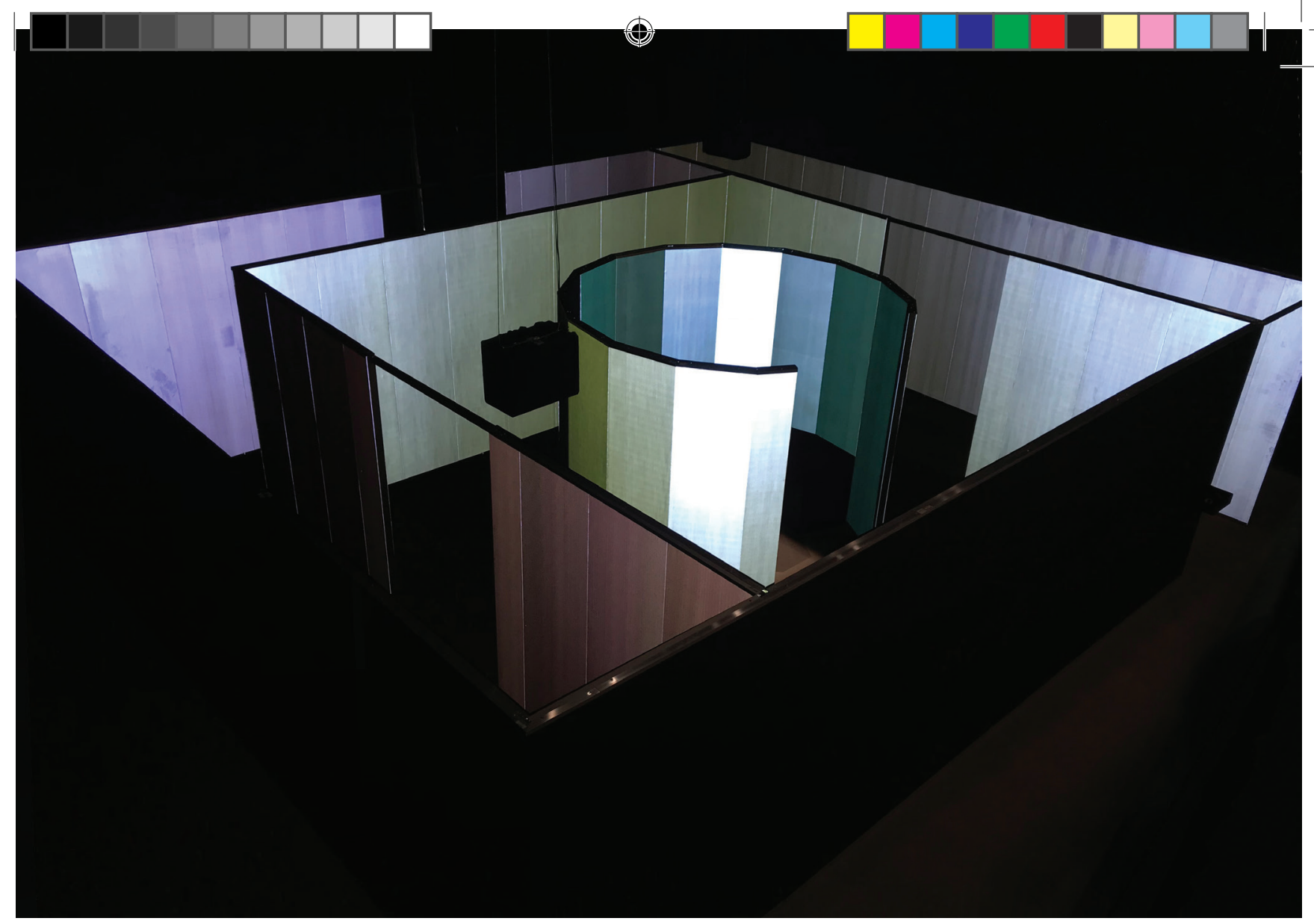

The Garden of Forking Paths.

lighting conditions, to see if there is any correlation or learning curve associated with this unconscious orientation learning process. The workshop I conducted with the visually impaired in Latvia also included a labyrinth that allowed visitors, with or without the aid of eyesight, to use their orientation skills to reach the centre, as a form of orientation training. ${ }^{13}$

\section{Missing Limbs}

Going back to neuroplasticity and Ramachandran, I managed to assist in the transfer of his famed mirror-box from California to the $14^{\text {th }}$ Istanbul Biennial. He developed it to allow those with amputated hands to overcome what is known as the 'phantom limb syndrome.' This is a condition that sometimes accompanies the loss of a limb, namely painful sensations where the lost limb would have been. In the mirror-box, the patient places his or her remaining hand through an opening in the box. A mirror in the middle of the box allows the patient to visually reconnect with a reflected view of the missing hand. Neurologically, the brain manages to adjust its body map until the phantom sensation diminishes. On this subject, I was also curious about the effect of hypnotic processes on the English drummer Rick Allen from the rock band Def Leppard. Allen lost his arm at the age of 21 in a car accident, and I was interested to know how neural pathways could be reconnected through unconscious methods, how these methods could have helped Allen bridge his own sense of a missing body map. We worked together to build visual ideations in which 'vehicles' would recover all their limbs, similar to how filmmaker Alejandro Jodorowsky
${ }^{13}$ The project, The Garden of Forking Paths, was part of the exhibition Portable Landscapes (Parnesajamas Ainavas) at the Latvian National Museum of Art, with the Latvian Centre for Contemporary Art. It was curated by Solvita Krese, Inga Lāce, Antra Priede-Krievkalne, Diāna Popova, and Andra Silapētere. 


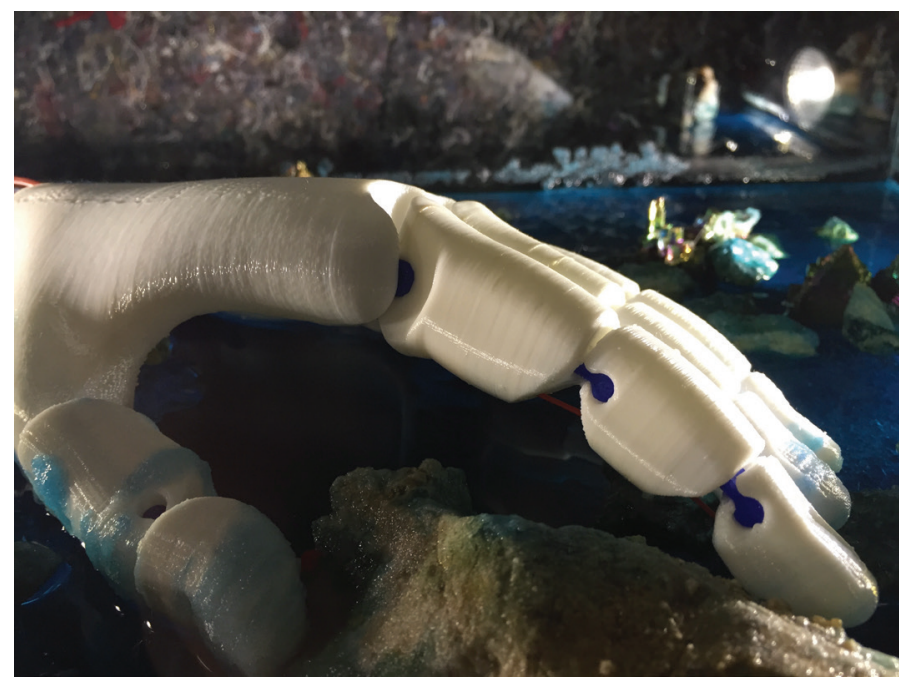

Prosthetic hand, Neuarthian Boatstrap. $14^{\text {th }}$ Istanbul Biennial.

prescribed exercises that link imagined realities and physical rituals in his book Psychomagic (2010). Interestingly, the recurring image that came to Rick Allen during his sessions was that of amphibians, some of which have the ability to regenerate- - such as the Mexican salamander, otherwise known as axolotl. To expand upon this research, I teamed up with the online network Enabling the Future at the Istanbul Biennial. Enabling the Future fosters an open source community for 3D printing prosthetic limbs for those who are unable to fund their own prosthetic treatment, particularly those who have been victims of ongoing, armed conflict, such as in Syria and Iraq. ${ }^{14}$

Based on the same premise as the project with the visually impaired (in which participants imagine colours that they cannot see), and by thinking about a sense modality that we have not yet incorporated into our existing collection of senses (such as echolocation by bats or chemoreception by snakes), what would happen if we incorporate an additional body part into our brain, or a sense organ that we have never used? Encouraging our own ability towards neuroplasticity would presumably allow us to do this.

\section{Sensory overload}

As a training ground for extended sensing, I built an assault course for the senses called Plantigrade. ${ }^{15}$ The title draws from the word (adjective) relating to how some mammals walk on the soles of their feet, such as bears and humans. The soles of our feet are incredibly sensitive, based on how many nerve endings are mapped into the brain according to the sensory homunculus map. Yet, in our industrialised societies, the neural nets related to the skin sensing in our feet have largely become dormant due to our use of shoes. In my installation, blindfolded visitors were invited to walk barefoot over various surfaces while touching different textures with their hands. The combination of different temperatures (due to heat conductance) and textures feeding through their feet and hands created a heightened sensory terrain and awakened new synaptic and neural pathways, not just related to touch, but also, according to reports of some of the visitors, to sounds and colours in a kind of provoked synaesthesia.
${ }_{14}$ The ${ }_{3} \mathrm{D}$ printing was carried out with the assistance of Northwestern University, Evanston, Illinois.
15 This was part of the exhibition Synaesthesia: What is the taste of the Color Blue? at Building Bridges Art Exchange in partnership with Art | Sci Center + Lab at University of California Los Angeles and International Association of Synaethetes, Artists, and Scientists. It was curated by Marisa Caichiolo. 


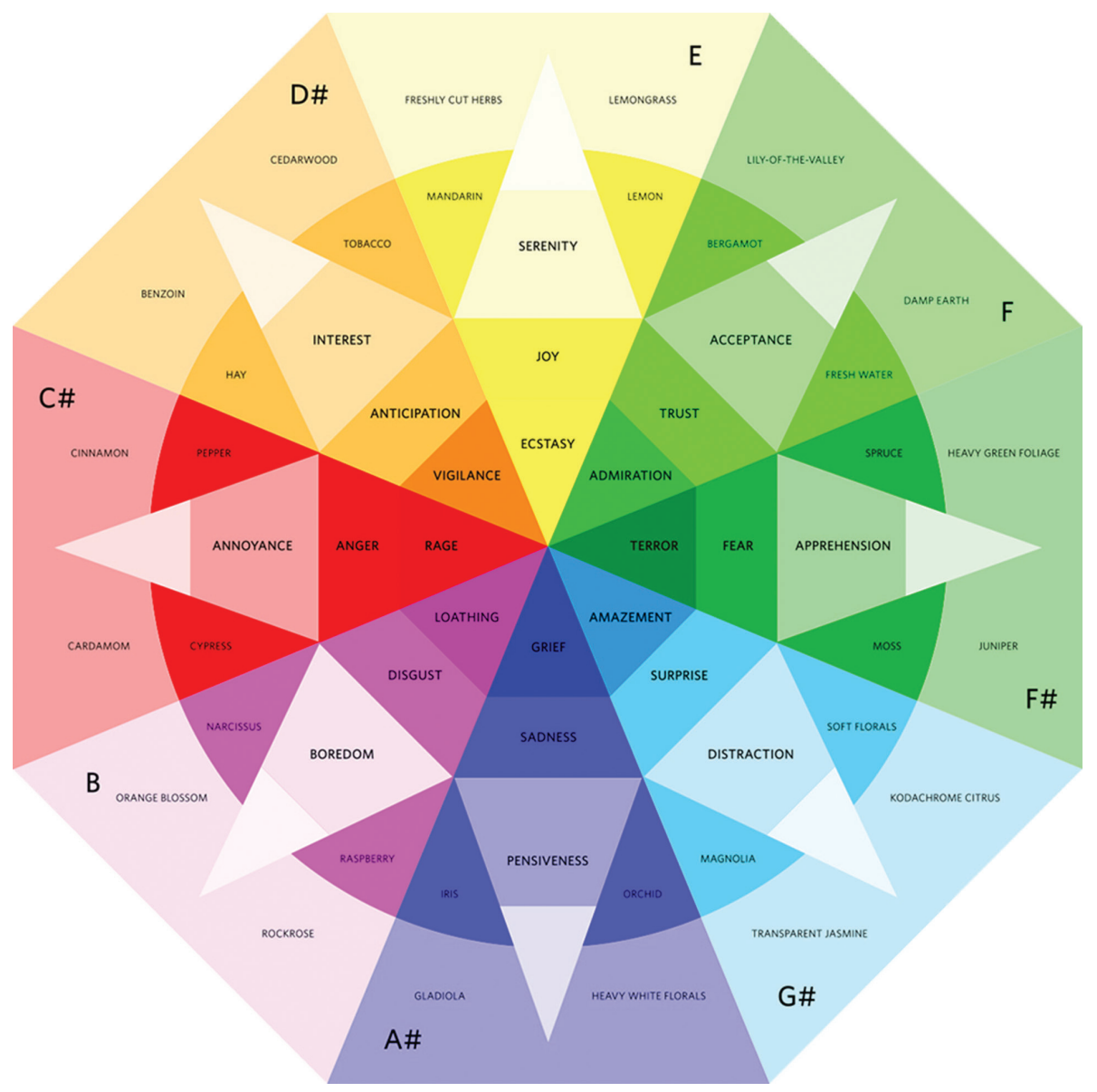

Synaesthetic wheel, The Memory Observatory. Portable Landscapes (Parnesajamas Ainavas).

\section{Colour Wheel}

In terms of the relationship beyond the senses, Robert Plutchik, Professor Emeritus at Albert Einstein College of Medicine, developed a colour wheel in 1980 linking what he termed psychoevolutionary theory of emotions (or eight key emotions) with biological fitness. I thought it would be interesting to extend this wheel to include other senses, such as smell and sound, and managed to deploy this experiment in an immersive installation called The Memory Observatory. I worked with Stephen V. Dowthwaite, who is recognised for having developed The ABCs of Perfumery, a basic system of odour classification that matches colour-emotions to smells. To extend the colour wheel into the auditory realm, I worked with sound designer Julia Owen. We based our associations on an amalgamation of sound theories. ${ }^{16}$ Major chords in E, F and B, for instance, are associated with bright, happy feelings while minor chords in $\mathrm{A} \#, \mathrm{C \#}$, and $\mathrm{D} \#$ often have dark, sinister tones that relate to sad emotions. By extending the wheel into different sense modalities, we are effectively de-pruning the brain and reconnecting dormant pathways that link emotions, memories and feelings to senses.
${ }^{16}$ Daniela and Bernd Willimek, Music and Emotions: Research on the Theory of Musical Equilibration (die Strebetendenz-Theorie) in http:// www.willimekmusic.de/music-andemotions.pdf. 


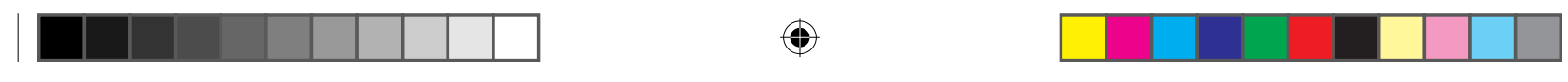

$\oplus$
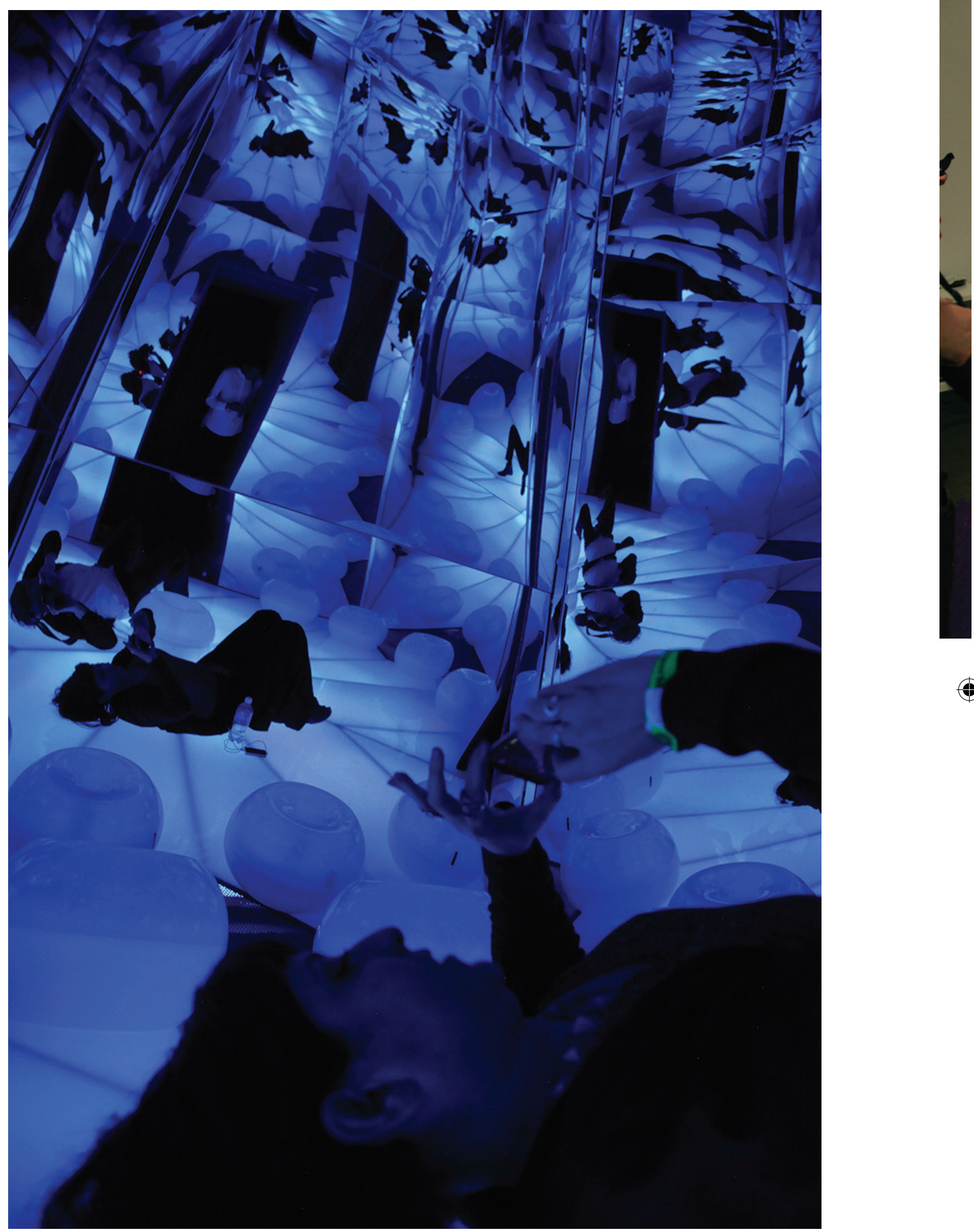

$\oplus$

The Memory Observatory. 


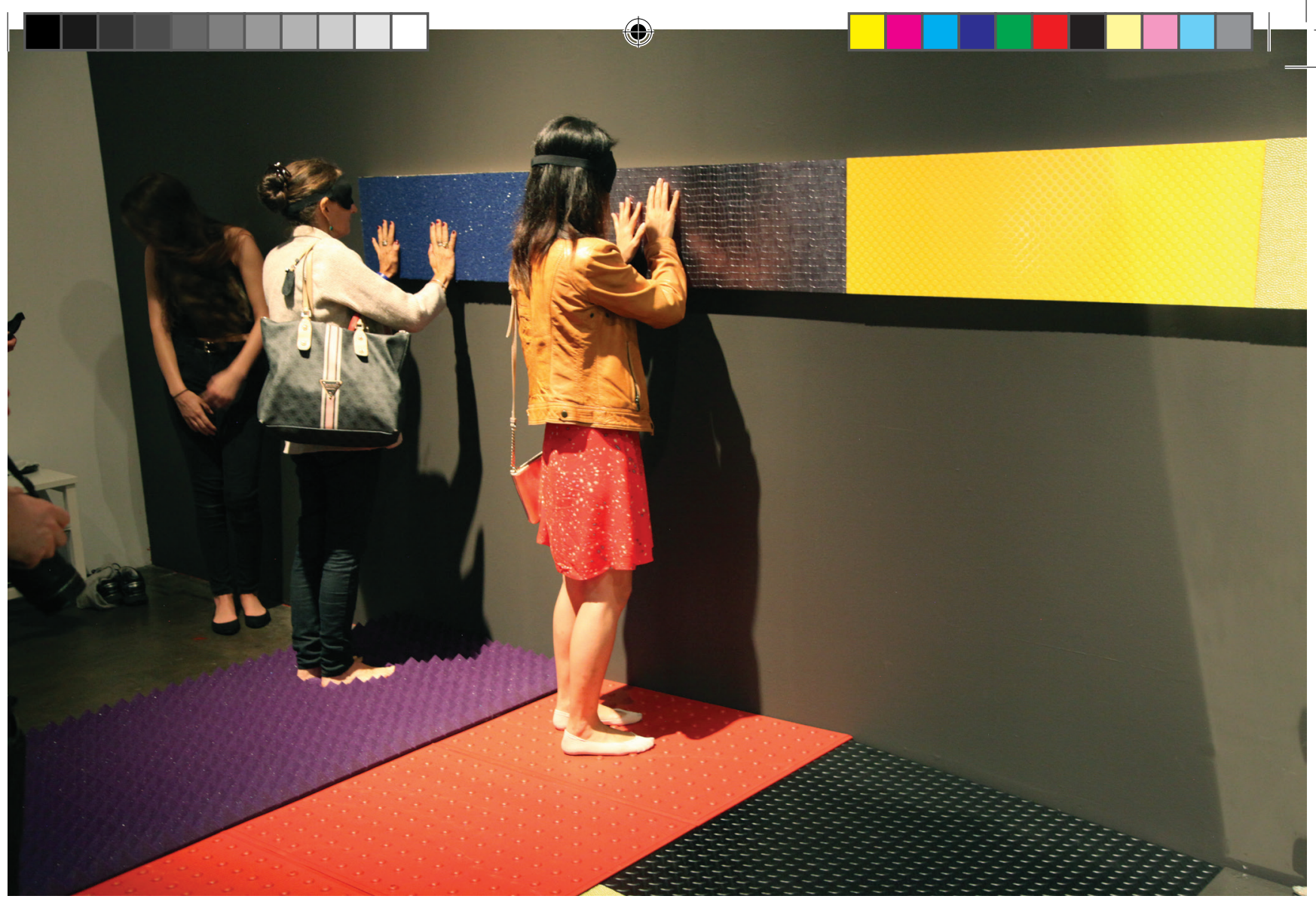

Plantigrade.

\section{Hypnotic Show}

The Hypnotic Show is another training ground I am working on in collaboration with Raimundas Malašauskas, and it is in the realm of mental gymnastics rather than sensory de-pruning. ${ }^{17}$ As the title implies, the performance project uses unconscious processes to create tautological situations, which the conscious mind cannot normally digest. Examples of this include: being in multiple places at once, focussing one eye on a foreground object and the other on the horizon, speaking backwards fluently while listening to a conversation in another language, feeling organic textures while considering mathematical integers. These exercises create a state of heightened neurological plasticity, which, over time and with practice, induce a state of broader perceptual experience and reality. Combined with sensory cues, such as odours concocted by renowned smell artist/chemist Sissel Tolaas, the hypnotic inductions can further be used to both construct and build new thought and memory structures of consciousness.

\section{Bridges and steps}

As a continued investigation into expanding ways of thinking and perceiving, my team and I are building a spiral staircase at Frye Art Museum in Seattle that will be populated with lingzhi (also called rishi) mushrooms. It is surprising to realise that mushrooms are closer relatives to animals than plants on the evolutionary path-they inhale oxygen and exhale carbon dioxide just like us. The staircase will sit within a large terrarium with mist cascading down the stair treads and lingzhi
17 This has been an itinerant performance project that celebrates its $10^{\text {th }}$ year anniversary in 2018 and has been shown in different countries and locations, which include: documenta 13, Centre Georges Pompidou and later in 2018, the 33 rd São Paulo Biennial. 
mushroom outcroppings. Visitors on nearby beanbags will listen to a hypnotic induction that uses the staircase as an imaginary, deepening, trance-inducing narrative feature. As one descends the staircase, both real and imaginary, in a trance-like state, engaging kinaesthetic mirror neurons, the possibilities of transiting between different states of consciousness are palpable. Just as the magnetotactic bacteria have a symbiotic relationship with turtles or geese, so too does the fungal root network or mycorrhizae establish connections between themselves and vascular host plants and, by extension, us.

The next steps in expanding consciousness would be to grow, encourage and enable new pathways in the brain that have never been activated. Whether this is achieved through unconscious mental gymnastics, physical assault courses, or a combination of both, is a matter of experimentation. This may seem to be an exotic and whimsical approach. Furthermore, the alternative of isolation from our natural surroundings, combined with highly-pruned and over-specialised thought processes, has brought about many astonishing technological feats. However, we are also in the era of the 'anthropocene': a time of mass extinction and the fastest environmental degradation that our planet has seen since the late Devonian period 375 million years ago.

The time has come to connect actively from within and without.

All photos courtesy of the author unless stated otherwise. 


\section{References}

Cronin, Thomas. "Seeing Without Eyes." Scientific American, 13 Aug 2017.

Debord, Guy. "Theory Of The Dérive." Les Lèvres nues \#9, November 1956. Print.

Eviatar, Natan and Vortman, Yoni. "The symbiotic magnetic-sensing hypothesis: do Magnetotactic Bacteria underlie the magnetic sensing capability of animals?" Movement Ecology, December 2017.

Jeanson, Yves. Volume 1: The Catalogue: On Zanis Waldheims' (19091993) Path. CreateSpace Independent Publishing Platform, 2017. Print.

Jodorowsky, Alejandro. Psychomagic: The Transformative Power of Shamanic Psychotherapy. Rochester: Inner Traditions, 2010. Print.

Lachman, Gary. "Climbing Mount Analogue." Quest 89.5, SeptemberOctober 2001, pp. 166-171. Print.

Lutyens, Marcos. Professor Vilayanur Ramachandran interviewed by Marcos Lutyens. https://vimeo.com/139512469.

McCormick, Kelly, Kim, Jee Young, List, Sara, and Nygaard, Lynne C. "Sound to Meaning Mappings in the Bouba-Kiki Effect." Proceedings of the 37th Annual Conference of the Cognitive Science Society, Pasadena, CA, July 2015 .

Willimek, D.B. Music and Emotions: Research on the Theory of Musical Equilibration (die Strebetendenz-Theorie)(2013). http://www. willimekmusic.de/music-and-emotions.pdf 